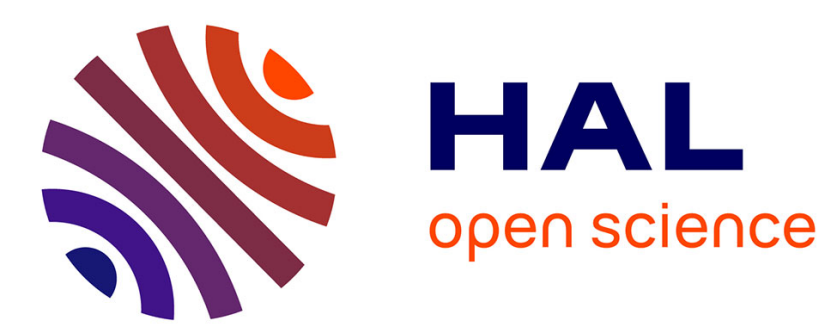

\title{
The transmission of voicing in traditional Gwoka: Between identity and memory
}

Marie Tahon, Pierre-Eugène Sitchet

\section{To cite this version:}

Marie Tahon, Pierre-Eugène Sitchet. The transmission of voicing in traditional Gwoka: Between identity and memory. Journal of Interdisciplinary Voice Studies, 2017, 2 (2), pp.157-175. 10.1386/jivs.2.2.157_1. hal-01593445

\section{HAL Id: hal-01593445 \\ https://hal.science/hal-01593445}

Submitted on 26 Sep 2017

HAL is a multi-disciplinary open access archive for the deposit and dissemination of scientific research documents, whether they are published or not. The documents may come from teaching and research institutions in France or abroad, or from public or private research centers.
L'archive ouverte pluridisciplinaire HAL, est destinée au dépôt et à la diffusion de documents scientifiques de niveau recherche, publiés ou non, émanant des établissements d'enseignement et de recherche français ou étrangers, des laboratoires publics ou privés. 


\title{
The transmission of voicing in traditional Gwoka: Between identity and memory
}

\begin{abstract}
This article examines the transmission of voicing - the use of voice during the execution of a song - in Gwoka music. Considered at the time of French colonization as mizik a vié nèg (vagrants music), this traditional music from Guadeloupe recently underwent a rehabilitation process that led to the idea that it reflected the "roots" and the "authenticity" of the Guadeloupe people. Gwoka music has since then become an important part of Guadeloupe cultural heritage, to the point that it is now listed on the UNESCO World Heritage List. The present work explores the relation between voicing in Gwoka and the questions of identity and memory. It defends the idea that traditional singers are chroniclers of their time. They are memory smugglers who educate the audience by evoking values through their lyrics and voice. Gwoka music is strongly attached to political movements of resistance since its emergence. Previous generations of singers have not only transmitted vocal practice and lyrics, but also Creole language. Finally, the ability of voicing to preserve the Guadeloupean identity and to resist Western domination is discussed in the last section.
\end{abstract}

\section{Keywords}

Gwoka, transmission, singing voice, identity, resistance, Guadeloupe 


\section{INTRODUCTION}

This article examines the transmission of voicing - the use of voice during the execution of a song - in Gwoka music. Considered at the time of French colonization as mizik a vié nèg, ${ }^{1}$ this traditional music from Guadeloupe recently underwent a rehabilitation process premised on the idea that it reflected the 'roots' and the 'authenticity' of the Guadeloupe people. Gwoka music has since then become such an important part of Guadeloupe cultural heritage that it is now listed on the UNESCO 'Representative List of Intangible Cultural Heritage of Humanity'.

Today, there is a need in Gwoka music, as well as in other traditional music, to preserve a living popular memory. Traditional music is usually part of daily life, a common expression that helps people to come together and maintain social links. Combining drum, song and dance, Gwoka is not only an artistic mode of expression for practitioners, but it is also an assertion of identity, a state of mind and a way of life. Throughout its history, Gwoka has functioned - and still does - as an outlet, offering an opportunity for freedom of expression. Gwoka is a symbol of cultural and political resistance and singers have played an important role in the rehabilitation process as reflected in the lyrics and vocal techniques pertaining to their songs.

This article positions traditional singers as chroniclers of their time. They are memory smugglers who educate the audience by evoking values through their lyrics and voice. While classical music has been extensively studied (pedagogical aspects, voice quality, performances, transmission), much fewer scholarly studies explore traditional music. Whereas ethnomusicologists tend to focus on the relations between music and social, political and cultural contexts, transmission processes have yet to be fully investigated, along with the relation between language and music, which has been left mostly unexamined. We will therefore provide new insights into the connection between Guadeloupean Creole language and Gwoka songs.

The goal of our interdisciplinary methodological approach is to provide an analysis of key elements of transmission in Gwoka music through the extraction of musical features from recorded songs performed by two generations of musicians. The results, interpreted through the lens of acoustic and ethnomusicological perspectives, demonstrate the significance of transmission processes across generations, since they ensure the continuity of the Creole language via metaphorical capacities and politically charged lyrics that assert Guadeloupean identity.

This article also foregrounds the 'westernization' of traditional cultures in Guadeloupe during the last decade. Western influences are considered as a potential attempt to exert control over expressions of cultural identity grounded in collective cultural memory. This is exemplified among singers by a loss of cultural 'authenticity' and linguistic capacity such as the use of metaphorisms, which are fundamental dimensions of Gwoka music, and by the fact that inclusion in UNESCO's 'Intangible Cultural Heritage of Humanity' category is based on western criteria and values.

In the first part, we introduce the historical context of Gwoka musical practices since their emergence in the seventeenth century until their integration into the 'Representative List of the Intangible Cultural Heritage of Humanity' in 2014, and we suggest these musical practices are linked to a political movement of resistance. In the second part, we examine the extent to which sites of transmission are key to the transgenerational continuity of this musical tradition. In the last section, we infer from our analysis of Gwoka voicing that it enables practitioners to assert their Guadeloupean identity and resist to western hegemony.

1 Creole terms are explained in Appendix. 


\section{HISTORICAL CONTEXT: GWOKA AS RESISTANCE}

\section{A musical genre born with the transatlantic slave trade}

Gwoka, a musical genre that emerged in the seventeenth century during the transatlantic slave trade, is the result of a creolization process: adaptation to surrounding context and assimilation of a few European culture elements. At that time, African slaves of Guadeloupe used to gather to play drums, sing and dance. The use of any kind of drum was at that time forbidden by the "Code Noir'. 'As a consequence, slaves used a vocal technique called bouladjel, which imitates drums. Gwoka practice was directly linked to agricultural work, especially sugar cane, coffee and banana cultivation. Gwoka music was - and still is - played throughout the year in various cultural manifestations such as léwòz, kout'tanbou, véyé and religious events, for example Advent's wake.

At the end of the nineteenth century, oral transmission of Gwoka was weakened because of social mutations. According to Oceane Chotard (2008), on the one hand, the Guadeloupean agricultural system was overwhelmed by western capitalism, and on the other hand, oral transmission was delegitimized when the French education system founded on written transmission was imposed by colonial power in Guadeloupe (Chotard 2009). As noted by Jacqueline Rosemain, 'the colonisation of the Guadeloupe Island has produced a loss of native culture then an acculturation process which are the consequences of all colonisations and has an impact on traditional practices' (1988).

\section{The role of Gwoka in Guadeloupean protests}

In 1946, many French colonies were assimilated into French administrative departments: Martinique, Guadeloupe, Algeria, etc. For people from the Antilles, assimilation was even worse than colonization: racist acts were still occurring against slaves' descendants and there was a strong tension between French métropole and old colonies. Influential public intellectuals such as Aimé Césaire, Rosan Girard and Albert Béville were questioning the assimilation process and campaigned for an autonomous status. Moreover, agricultural farms were closing one after the other, thus increasing unemployment on the islands. Construction industries, directed by French entrepreneurs, absorbed most of the agricultural employees. In 1967, the French government employed military force to repress salary claims and strikes. According to the French Human Rights League, the intervention resulted in a violent massacre (Ligue des droits de l'homme 2013). This tragic event is evoked in the book Mé 67 by Raymond Gama and Jean-Pierre Sainton (1985).

Jointly with anti-assimilation and anti-colonialism movements, Gwoka, which had its origin in rural areas, spread throughout the whole island, which marks the beginning of its rehabilitation process while also constituting a form of protest and an expression of identity. As a consequence, in 1988, lawyer and nationalist activist Félix Cotellon created the 'Festival de Gwoka Sentann' (FGK) in the city of Sainte-Anne without the support of the municipality. Studies and symposiums were then organized outside the festival. In the 1970s, Gwoka became a recognized genre thanks to the talented guitarist Gérard Lockel who was the first musician to theorize this musical style. The Traité de Gwoka modên written by Lockel in 1981 attempts to formalize this music. However, this work is complicated and is not in line with the oral transmission tradition. Moreover, the acceptance of Lockel's work is conditioned by his political engagement as an activist advocating for independence (Chotard 2009). Among other assertions, Lockel affirmed that Gwoka was an atonal-modal music, thus

2 The 'Code Noir' was a decree passed by France's King Louis XIV in 1685. This code defined the conditions of slavery in French colonial empire. The gist of the code remained in place until 1848 . 
causing a huge polemic among musicians. Lockel claimed that Gwoka was a 'class struggle music for Guadeloupean workers and farmers' (1981). According to Jerome Camal, by claiming that Gwoka was atonal, Lockel breached with western conventions and tastes, and by affirming the modality of Gwoka, he situated this music style within the realm of African musical traditions (Camal 2013). Even if such theories were rather dogmatic in nature, they helped to eradicate the vié nèg or trivial approach. Lockel also refused to use the western notation system to explain and theorize Gwoka music, which was in total opposition with French norms. Camal specifies: 'in Guadeloupe, under the leadership of Gérard Lockel, Gwoka was transformed from a participatory music played outdoors to a presentational music played on stage with European and North American instruments' (2011). At that time, performance opportunities were limited to léwòz, kout'tanbou, véyé and friends' houses. On the politico-syndicalist and nationalist movement's initiative, a large concert hall for popular tradition, called Centre des Arts et de la Culture, was created in Pointe-à-Pitre in 1978. Many stars of Gwoka and other styles of music from the Caribbean islands have played on this stage. Since, more and more concerts of Gwoka music occurred in Guadeloupe, France and all over the world.

\section{Gwoka and humanity's intangible cultural heritage}

On Félix Cotellon's initiative, a non-governmental organization, called Rèpriz, Centre régional des musiques et danses traditionnelles et populaires de Guadeloupe (Regional Centre for Traditional Guadeloupean Popular Music and Dance), was created in 2005. The centre was dedicated to the conservation of intangible cultural heritage, the support of transmission and artistic teaching, as well as the diffusion and promotion of music and artists from Guadeloupe. While Gwoka was frowned upon for decades, it is now one of the most famous and appreciated - music and dance genres in Guadeloupe. Scientific researchers such as the singer Marie-Hélèna Laumuno are now studying aspects of Gwoka from a musicological or ethnological point of view and organize Caribbean ethnomusicology seminars $(2011,2012$, 2013). Some linguistic works on Creole languages have also begun to appear, including two Ph.D. theses focusing on the linguistic, phonetic and phonological analysis of French Creole languages (Delumeau 2006; Sainton 2006). Gwoka was included in the UNESCO 'Representative List of the Intangible Cultural Heritage of Humanity' on 26 November 2014.

The animated debates that took place before 2014 regarding this inclusion prove that the practice of this musical art is a crucial element of Guadeloupean culture, and also that this heritage is a major concern for musicians. A few of them, constituted as a collective, have fought against registration of Gwoka on the list, arguing that this music did not need to be included because it had 'survived' and would remain a vibrant cultural practice on its own terms. They were also afraid of a potential colonialist attempt by the French government to control their cultural heritage via UNESCO and saw no necessity for any 'guardianship' or 'sponsorship'. In his critique of UNESCO's conception of culture, Thomas Hylland Eriksen also highlights the fact that intangible cultural heritage is governed by western countries (2001). He states: 'Our Creative Diversity invokes several concepts of culture, but it is dominated by the classic view from cultural relativism [...] of cultures as bounded entities with their own sets of values and practices'. It has therefore been necessary for the NGO Rèpriz to develop various strategies that raise the awareness within the Guadeloupean population and foreground the advantages and the necessity of the inclusion of Gwoka in the Representative List of the Intangible Cultural Heritage managed by UNESCO. 


\section{Gwoka and the quest for a Guadeloupean identity}

First considered as mizik a vié nèg, Gwoka underwent a rehabilitation process in the twentieth century followed by an attempt to return to the 'roots' and the 'authenticity' of this traditional cultural practice. According to Marie-Céline Lafontaine, since Gwoka is the only musical genre which represents a direct link between ancestral slaves and the African continent, it embodies the Guadeloupean identity (1983). In their quest for 'authenticity', Gwoka musicians privilege some constitutive elements, which they consider as a legacy of ancestral African musical practices. In the very similar context of Marie-Galante island (located near Guadeloupe), Ron Emoff stresses it is not historical facts that prevail, but truths that are cultural constructions (2009). Yet even if some of Gwoka musician's assertions regarding their ancestry's music are not accurate, this does not weaken the strength of the link that connects Guadeloupean people to Africa.

Gwoka is characterized by UNESCO and by traditional musicians through the combination of three fundamentals aspects: a repetitive question-answer structure, rhythm played by $k a$ drums, and dance (UNESCO 2014). Dance is not investigated in the present study that focuses solely on music. The bouladjèl - sometimes called bannjogita - is a traditional musical expression specific to the mainland of Guadeloupe and one of the constitutive elements of Gwoka. Initially practiced exclusively by men, the bouladjèl is intended to accompany songs, primarily during wakes. Today, women also sing the bouladjèl except during wakes. For example, women sing the bouladjèl during the léwòz or the kout'tanbou. Bouladjel is based on a polyrhythmic combination of public hand raps and percussive vocalizations during which intertwined throat noises are associated with onomatopoeias, which are vocal transposition of Gwoka rhythms, and gasps (Patrimoine Culturel Immatériel 2012).

Gwoka is also characterized by a repetitive question-answer (chantè and répondè) structure sung in Guadeloupean Creole exclusively. Gwoka practice combines improvisational skills with the use of humour and the artistic expression of emotions. The Creole accent is part of the criteria that nurture the aesthetics judgements called santiman and lokans. Another fundamental feature of Gwoka is the primacy of rhythmic structure. One must not forget that Gwoka relies on music, singing and dance. While santiman is related to feelings and emotions, lokans mostly refers to the vocal power of the singer, his or her virtuosity and ability to captivate the audience. As such, two drums called $k a$ are particularly important: the make translates the dancer's gestures and attitudes into sounds while the boula plays a rhythmic ostinato on which the dancer will improvise (UNESCO 2014; Lameca 2015).

\section{VOICING AS A KEY ELEMENT OF TRANSMISSION PROCESS}

From the beginning of the transatlantic slave trade until its inclusion in the UNESCO 'Representative List of the Intangible Cultural Heritage of Humanity', Gwoka music has been associated with protests, strikes, as well as with political and social engagement. Gwoka has played a major role in the quest for Guadeloupean identity and, today, it constitutes a living memory for people who self-identify as natives of the island. Focusing on vocal practices in Gwoka music, we will examine the main characteristics of transmission processes and discuss the significance of these processes within the specific socio-political context of Guadeloupe. 


\section{Sites of transmission}

Prior to the 1970s, Gwoka was transmitted transgenerationnally by elders in the familly. This is the case of the Geoffroy family, with whom Pierre-Eugène Sitchet worked, where transmission took place across three generations. Born in the 'Grands-Fonds' where they were farmers, Owa (1921-2008) and Evariste (1918-2008) were Gwoka singers, and four of their thirteen children also became Gwoka musicians. At present, the grandsons sing répondè or bouldjel in the band Kan'nida with the second generation of Geoffroy singers. ${ }^{3}$ Gwoka was also transmitted by immersion through participation in the léwòz, the kout'tanbou, etc. At home or at friends' home, during the léwòz or kout'tanbou, transmission consisted in observing and mimicking more experienced singers, dancers and tanbouyés. When Gwoka schools appeared in the 1980s, transmission became more formalized. Schools and Gwoka organizations offered internships of one to two weeks, as well as year-long training. However, even in Gwoka schools, there are no formal teaching classes. Students learn a repertoire and teachers encourage them to go to the léwòz and the kout'tanbou. Students learn through immersion in live cultural practice and through the imitation of more established singers. Gwoka is also transmitted through audio-visual recordings. Today, following Lockel's Traité, many methods are proposed to young students to facilitate the learning of $k a$ drumming.

As regards the transmission of traditional songs, very few scholarly studies are available. In his book on the transmission of Irish songs, Jerry DeWayne Kerlin highlights the importance of intergenerational transmission (2008). Studies on music transmission focused on traditional singers are quite rare in comparison with those focused on western classical singers. The two main reasons for this are the extremely high diversity of traditional music around the world, each being practiced by far less people than classical western music, the second reason being a consequence of the first, namely the fact that classical music is privileged in western societies due to a dominant cultural bias.

\section{Voice in traditional music}

In the context of traditional music, the voice may be considered as instrument as well as part of the singer's body. According to Simon Frith,

[m]usic, like identity, is both performance and story, describes the social in the individual and the individual in the social, the mind in the body and the body in the mind; identity, like music, is a matter of both ethics and aesthetics. (1996)

Therefore, the singer as a person is part of a social group's cultural heritage as underlined by Labarthe (1998). Voice as a musical instrument has been extensively studied from physical and physiological points of view, yet most of these studies investigate classical singing. Among the few other studies focusing on traditional popular music, some employ acoustic analysis - for example in studies examining Portuguese Fado (Mendes et al. 2012), or Mongolian throat singing (Lindestad et al. 2001) or Croatian songs (Boersma and Kovaccic 2006) - while others attempt to foreground the effects of spoken language on singing techniques (Ambrazeviccius and Leskauskaite 2007; Livingstone et al. 2013).

While the Creole language has been studied from a linguistic point of view (Delumeau 2006; Sainton 2006), as far as we know the relationship between language and song has not yet been explored. The authors have presented their research on the role of voice in Gwoka tradition at conferences held in France, the United Kingdom and Guadeloupe. In previous studies, the authors developed an interdisciplinary approach based on the automatic extraction of acoustic voice descriptors for both spoken and sung signals. By comparing spoken and

$3 \mathrm{https}$ //kannidainternational.bandpage.com/. 
sung voices using this approach, the authors have highlighted some key elements of voicing in Gwoka such as nasality (Tahon and Sitchet 2016) and consonant assimilation - in this case, unvoiced spoken consonants are assimilated to voiced sung consonants (Sitchet and Tahon 2016).

\section{Methodology for analysing the transmission of voicing between two generations of singers}

Our analysis of voicing transmission processes relies for the most part on an acoustic analysis of four songs performed by six major Gwoka performers of different generations (see Table 1), including the legendary artists Robert Loyson and Sergius Geoffroy, known as some of the best singers in Guadeloupe. The present analysis will provide the opportunity of highlighting the similarities and differences between two generations of singers with respect to the transmission of the tradition. Indeed, acoustic analysis enables us to identify which vocal characteristics are transmitted in Gwoka, while the ethnomusicological approach enables us to understand why.

\begin{tabular}{llll} 
Song & Singer & Date of birth & $\begin{array}{l}\text { Date of } \\
\text { recording }\end{array}$ \\
$\begin{array}{l}\text { Delayi Maoba } \\
\text { Delayi Maoba }\end{array}$ & Wozan Monza & 1967 & 2015 \\
Dimanche Gran Bon Maten & Rene Geoffroy & 1952 & $\begin{array}{l}\text { recent } \\
\text { Majo la (Dimanche Gran Bon }\end{array}$ \\
$\begin{array}{l}\text { Maten) } \\
\text { Kan Siren la Sonne }\end{array}$ & Hilaire Geoffroy & $1958-2011$ & 1962 \\
$\begin{array}{l}\text { Kan Siren la Sonne } \\
\text { Ô Lèonso alon monte }\end{array}$ & Robert Loyson & $1928-89$ & $1960-70$ \\
$\begin{array}{l}\text { Ô Lèonso alon monte (kaladja } \\
\text { tumblak) }\end{array}$ & Kristen Aigle & 1967 & 2015 \\
\hline
\end{tabular}

Table 1: Corpus of analysed songs.

Classical western music studies usually rely on written materials - scores - that enable to generalize the results. Traditional music studies that rely on transcribed scores in order to generalize individual performances introduce a strong bias. Indeed, symbols and notations used for transcription were created for classical western music and are not able to capture specific structures and practices. Current traditional music studies tend to rely on various recordings of the same song performed under different conditions (performer, context) in order to be able to generalize the results. In order to take advantage of the diversity of recordings, some ethnomusicologists employ automatic feature extraction from the audio signal as well as machine learning tools, as demonstrated in some of the proceedings of the last Folk Music Analysis workshops. ${ }^{4}$ In our research project, we set up a methodology that follows this approach.

In the present article, different cues are investigated as potential descriptors of vocal practices. Among them, some cues are related to the song structure and rhythm, others to voice quality or to the melody. Most of the structural and rhythmic cues are extracted

4 https://fma2015.sciencesconf.org/; https://fma-2016.sciencesconf.org/. 
automatically using Vamp plugins (tempo, beats and musical notes). ${ }^{5}$ Voice quality features are extracted automatically from voiced signals using Praat - signals produced while vocal folds are vibrating (jitter, voiced ratio and harmonic-to-noise ratio). ${ }^{6}$ Additional spectrograms have been extracted at the beginning of each performance to identify specific vocal aspects such as vibrato, glissandi and portamenti. A manual segmentation of the structure (répondè, chantè and solos) is realized using Transcriber (Barras et al. 2000).

\section{Research findings: Voicing as a key element in transmission processes}

Values and notes for the analysis of the different songs are reported in Table 2. Regarding the overall structure and rhythm, introduction always begins slowly and tempo increases during the first three (or four) question-answers. Both generations of singers have either stable or variable beats. Durations of répondè and chantè do not vary according to generation, but on the contrary, they seem to be very stable through generations for each song, as if the lyrics and melody were transmitted along with specific forms of improvisation (straightforward, rubato, etc.).

Gwoka songs are highly voiced, in the sense that vocal folds almost always vibrate (Sitchet and Tahon 2016), and that all singers use vibrato, glissando and portamento in their melodic contours as shown by the fundamental frequency (F0) curve on spectrograms on Figure 1. For example, chantè nearly always ends with a drop in the F0 (i.e. a falling glissando) as shown on the spectrograms (Figure 1). The differences are not dependent on generations, but on singers.

No significant differences have been found in the voice quality descriptors such as jitter, voiced ratio and harmonic-to-noise ratio. We also highlighted the systematic nasalization of consonants and vowels in Gwoka singing. Nasalization, as non-verbal cue, is a way of intensifying the expression of emotions such as sadness, nostalgia or complaint (Fox 2004). However, it appears that singers from the recent generation tend to resort more frequently a creaky voice than singers from the former generation. The creaky voice is known as being rarely used in spoken French, but is very frequent in American English. Its use might thus be an influence from the United States of America.

In the first section of this article, we discussed three fundamental features of Gwoka identified in the description provided by UNESCO: a repetitive question-answer (chanté and répondé) structure sung in Guadeloupean Creole exclusively as well as the primacy of rhythm and of dance. In the end, the analysis of acoustic features extracted automatically and manually from the signal confirms the significance of these three aspects except for dance that is not part of our study. No differences in voice quality were discovered between generations, except for creaky voice. The presence of bouladjel in former and recent generations confirms its importance for Gwoka. The question-answer structure, the relative durations of questions and answers, as well as the global rhythm (beats, regularity, and tempo) are also transmitted across generations. Finally, the following features can be added: voice quality and the use of vocal techniques (referred to as voicing) such as vibrato, portamento and glissando, which are constitutive of the sounds themselves.

However, the global structure and the role of each instrument including voice, especially in the introduction and the conclusion of each song, tend to change across generations. Gwoka musical performances demand a huge input from the singer so as to captivate the audience's attention with his or her powerful voice and his or her improvisation skills (lokans), especially during wakes or funerals. Thus, it is not surprising that vocal improvisations play a more pivotal role in current generations than in former generations, thereby emphasizing the

5 http://www.vamp-plugins.org/.

$6 \mathrm{http}: / /$ www.fon.hum.uva.nl/praat/. 
importance of lokans.

\begin{tabular}{|c|c|c|c|c|}
\hline Song & Delayi Maoba & Delayi Maoba & $\begin{array}{l}\text { Ô Lèonso alon } \\
\text { monte }\end{array}$ & $\begin{array}{l}\text { Ô Lèonso alon } \\
\text { monte }\end{array}$ \\
\hline Singer & Wozan Monza & Rene Geoffroy & Kristen Aigle & $\begin{array}{l}\text { Ibernat \& André } \\
\text { Broussillon }\end{array}$ \\
\hline Date of recording & recent & recent & $1970^{\prime}$ & 1992 \\
\hline Introduction & $\begin{array}{l}\text { tempo } \\
\text { annoucement }+ \\
\text { theme }\end{array}$ & $3 \mathrm{QA}$ & $6 \mathrm{QA}$ & $4 \mathrm{QA}$ \\
\hline Solo ? & drum solo as A & $\begin{array}{l}\text { drum solo at the } \\
\text { end }\end{array}$ & drum solo as A & $\begin{array}{l}\text { drum solo at the } \\
\text { end }\end{array}$ \\
\hline Duration total (sec) & 287 & 178 & 261 & 327 \\
\hline Bouladjel ? & yes & & & \\
\hline Tempo (bpm) & 98 & 110 & 120 & 127 \\
\hline Tempo (quality) & stable & $\begin{array}{l}\text { Increases in the } \\
\text { beginning }(<8 \mathrm{sec})\end{array}$ & $\begin{array}{l}\text { Increases in the } \\
\text { beginning }\end{array}$ & $\begin{array}{l}\text { Increases all the } \\
\text { time, movement at } \\
150 \mathrm{bpm}\end{array}$ \\
\hline Beat Period (sec) & 0.45 & 0.4 & 0.50 (end) & 0.45 (end) \\
\hline Beat (quality) & Stable & Stable & Variable & Variable \\
\hline Duration A (sec) & $\begin{array}{l}\text { Moy=140; } \\
\text { std } 58\end{array}$ & $\begin{array}{l}\text { Moy=124; } \\
\text { std=11.4 }\end{array}$ & $\begin{array}{l}\text { Moy=212; } \\
\text { std=36 }\end{array}$ & $\begin{array}{l}\text { Moy=196; } \\
\text { std }=18\end{array}$ \\
\hline Duration Q (sec) & $\begin{array}{l}\text { Moy=457; } \\
\operatorname{std}=137\end{array}$ & $\begin{array}{l}\text { Moy=306; } \\
\operatorname{std}=56\end{array}$ & $\begin{array}{l}\text { Moy=205; } \\
\operatorname{std}=50\end{array}$ & $\begin{array}{l}\text { Moy=200; } \\
\text { std }=45\end{array}$ \\
\hline $\begin{array}{l}\text { Ratio duration } \\
\text { R/Total }\end{array}$ & 1.59 & 1.72 & 0.79 & 0.61 \\
\hline $\begin{array}{l}\text { Duration Q } \\
\text { (quality) }\end{array}$ & Variable & Slightly decreasing & Slightly decreasing & Slightly decreasing \\
\hline notes & $\begin{array}{l}\text { 100(drum); } \\
\text { 168(Mi2); } \\
\text { 196(Sol2); } \\
\text { 220(La2); } \\
266(\mathrm{Do} 3) ; \\
296(\mathrm{Ré} 3) ; \\
327(\mathrm{Mi} 3) ; \\
\text { 397(Sol3) }\end{array}$ & $\begin{array}{l}\text { 100(drum); } \\
\mathrm{f}=173(\mathrm{Fa} 2) ; \\
227(\mathrm{La} 2) ; \\
278(\mathrm{Do} \# 3) ; \\
313(\mathrm{Ré \#}) ; \\
346(\mathrm{Fa} 3)\end{array}$ & $\begin{array}{l}\text { 75(drum); } \\
246(\mathrm{sI} 2) \\
291(\mathrm{Ré} 3) \\
\text { 323(Mi3); } \\
\text { 380(Fa\#3) }\end{array}$ & $\begin{array}{l}\text { 100(drum); } \\
\text { 172(Fa2); } \\
236(\mathrm{La} \# 2) ; \\
290(\mathrm{Ré} 3) ; \\
346(\mathrm{Fa} 3) ; \\
397(\mathrm{Sol} 3)\end{array}$ \\
\hline Unvoiced ratio (\%) & 6.4 & 1.7 & 5.1 & 6.7 \\
\hline Jitter (\%) & 1.2 & 1.62 & 1.1 & 1.3 \\
\hline HNR (dB) & 13.6 & 10 & 13 & 10.1 \\
\hline Creaky voice? & yes & no & no & no \\
\hline
\end{tabular}




\begin{tabular}{|c|c|c|c|c|}
\hline Song & $\begin{array}{l}\text { Kan Siren la } \\
\text { Sonne }\end{array}$ & $\begin{array}{l}\text { Kan Siren la } \\
\text { Sonne }\end{array}$ & $\begin{array}{l}\text { Dimanche Gran } \\
\text { Bon Maten }\end{array}$ & $\begin{array}{l}\text { Dimanche Gran } \\
\text { Bon Maten }\end{array}$ \\
\hline Singer & Robert Loyson & Wozan Monza & Sergius Geoffroy & Hilaire Geoffroy \\
\hline Date of recording & 1960-1970' & 2015 & 1962 & 2002 \\
\hline Introduction & $2 \mathrm{QA}$ & & $3 \mathrm{QA}$ & Bouladjel + 3 QA \\
\hline Solo ? & $\begin{array}{l}\text { Singer solo + } \\
\text { drum/ } \\
\text { bouladjel solo }\end{array}$ & & no & $\begin{array}{l}\text { singer/drum solo }+ \\
\text { drum solo at the } \\
\text { end }\end{array}$ \\
\hline Duration total (sec) & 358 & 251 & 149 & 128 \\
\hline Bouladjel ? & & & yes & yes \\
\hline Tempo (bpm) & 110 & instable & 112 & 112 \\
\hline Tempo (quality) & $\begin{array}{l}\text { Increases in the } \\
\text { beginning }(<8 \mathrm{sec})\end{array}$ & & $\begin{array}{l}\text { stable (in the end } \\
\text { tempo reaches } 154 \\
\text { bpm) }\end{array}$ & $\begin{array}{l}\text { Increases in the } \\
\text { beginning, falls, } \\
\text { then increases } \\
\text { again }(<28 \mathrm{~s})\end{array}$ \\
\hline Beat Period (sec) & 0.55 & $?$ & 0.50 & 0.50 (end) \\
\hline Beat (quality) & Stable & Variable & Variable (end) & Decreasing \\
\hline Duration A (sec) & $\begin{array}{l}\text { Moy=684; } \\
\operatorname{std}=1145\end{array}$ & $\begin{array}{l}\text { Moy=506; } \\
\text { std=98 }\end{array}$ & $\begin{array}{l}\text { Мoy=129; } \\
\text { std=26 }\end{array}$ & $\begin{array}{l}\text { Мoy=153; } \\
\text { std=82 }\end{array}$ \\
\hline Duration Q (sec) & $\begin{array}{l}\text { Moy=1875; } \\
\text { std=3396 }\end{array}$ & $\begin{array}{l}\text { Moy=2124; } \\
\text { std=3367 }\end{array}$ & $\begin{array}{l}\text { Moy=315; } \\
\text { std=83 }\end{array}$ & $\begin{array}{l}\text { Moy=273; } \\
\text { std=59 }\end{array}$ \\
\hline $\begin{array}{l}\text { Ratio duration } \\
\text { R/Total }\end{array}$ & 5.24 & 8.46 & 2.11 & 2.13 \\
\hline $\begin{array}{l}\text { Duration Q } \\
\text { (quality) }\end{array}$ & Stable & Stable & Stable & Stable \\
\hline notes & $\begin{array}{l}\text { 154(Ré\#2); } \\
\text { 205(Sol\#2); } \\
\text { 234(La\#2); } \\
250(\mathrm{Si} 3) ; \\
303 \text { (Ré\#3) }\end{array}$ & $\begin{array}{l}\text { 152(Ré\#2); } \\
\text { 183(Fa\#2); } \\
\text { 212(Sol\#2); } \\
\text { 224(La2); } \\
270(\text { Do\#3) }\end{array}$ & $\begin{array}{l}\text { 96(Sol1); } \\
\text { 206(Sol\#2); } \\
226 \text { (La2); } \\
260 \text { (Do3); } \\
\text { 297(Ré3) }\end{array}$ & $\begin{array}{l}\text { 118(La\#2); } \\
\text { 161(Mi2); } \\
\text { 207(Sol\#2); } \\
231(\text { La\#2); } \\
289 \text { (Ré3 }\end{array}$ \\
\hline Unvoiced ratio (\%) & 13.6 & 7.5 & 4.4 & 7.5 \\
\hline Jitter (\%) & 1.3 & 1.3 & 1.3 & 3.7 \\
\hline HNR (dB) & 11.9 & 12.9 & 14.1 & 5.2 \\
\hline Creaky voice? & no & yes & no & yes \\
\hline
\end{tabular}

Table 2: Research findings concerning the different rhythmic, structural and melodic cues. These numbers must be handled with care, especially automatically extracted cues, because the original signal qualities differ significantly from one to another (for example unvoiced ratio, HNR and jitter are highly sensitive to the presence of noise and percussive instruments). NB1: Q refers to Question and A to Answer. NB2: the song 'Kan siren la sone' by Wozan Monza was recorded a capella, therefore only voice quality can be analysed on this song.

One of the main differences between generations is the relative function of singer or percussion solos. Indeed, melodic variations in the chantè reach a higher range of notes in new generations than in old ones for which variations remain very close to the theme. Some singers add drums to the vocal bouladjèl. The reason is that few people are able to keep singing the whole night during the wakes with the bouladjèl as the only accompaniment. 


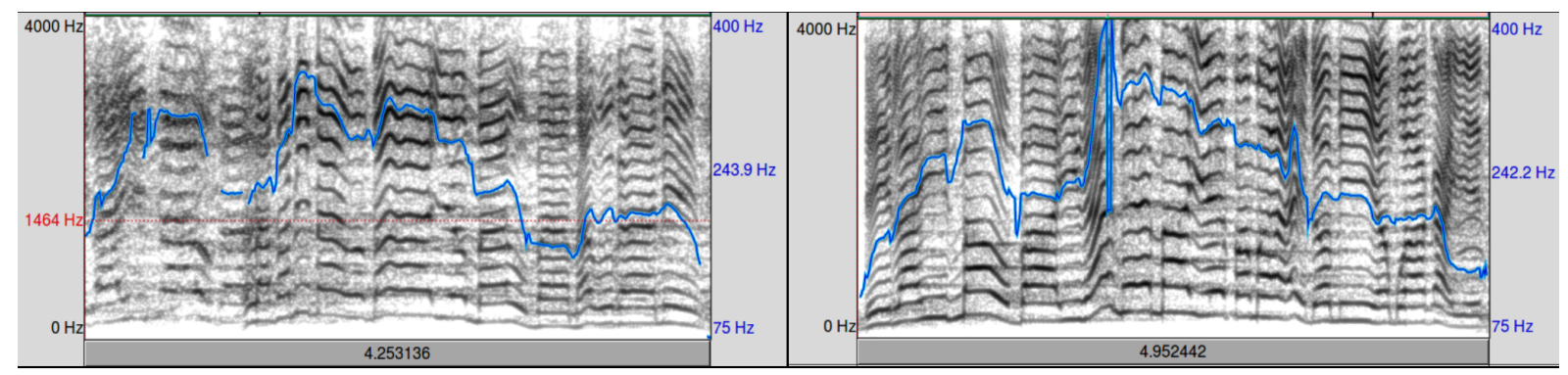

Figure 1a: Delayi Maoba, Renè Geoffroy

Figure 1b: Delayi Maoba, Wozan Monza

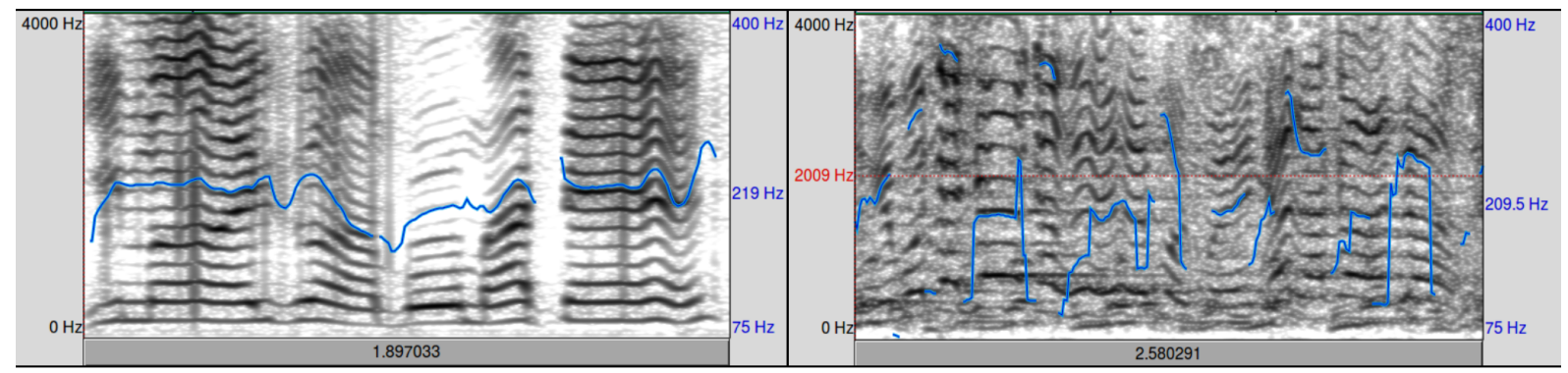

Figure 1c: Dimanche Gran Bon Maten, Sergius Geoffroy

Figure 1d: Dimanche Gran Bon Maten, Hilaire Geoffroy

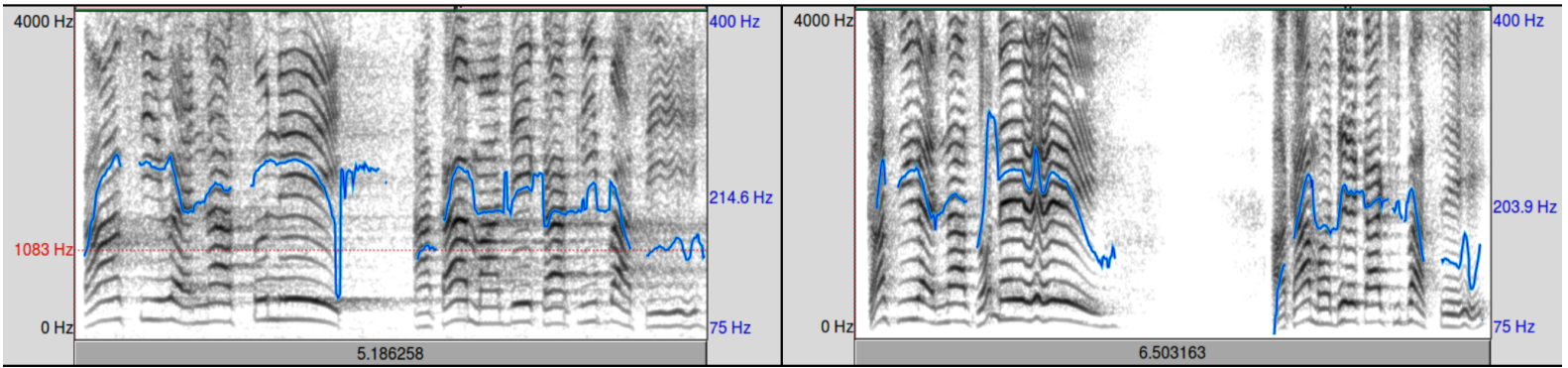

Figure 1e: Kan Siren La Sonne, Robert Loyson

Figure 1f: Kan Siren La Sonne, Wozan Monza

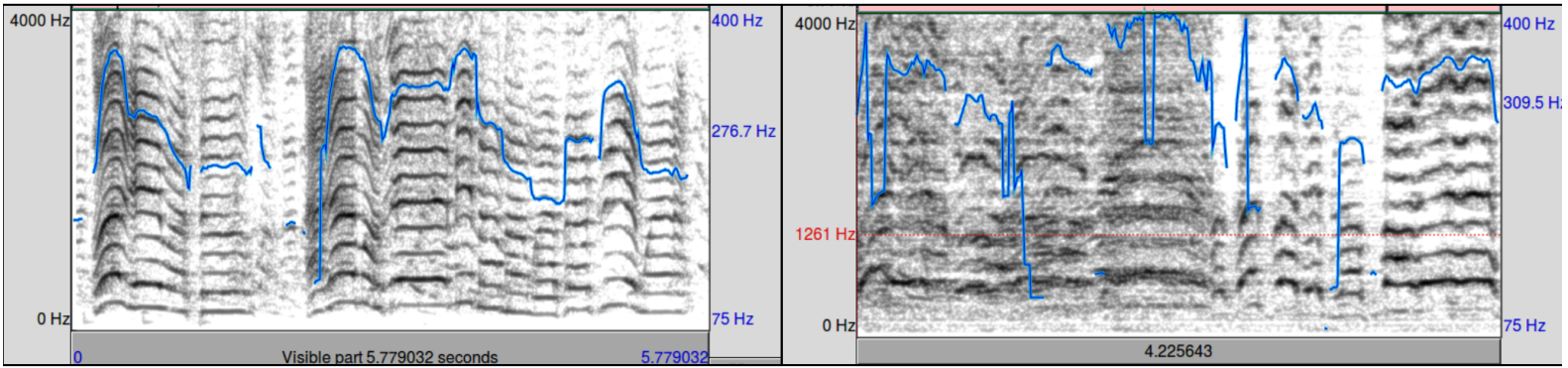

Figure 1g: Ô Léonso, Kristen Aigle

Figure 1g: Ô Léonso, Ibernat and Andrè Broussillon

Figure 1: Spectrograms of the first seconds where soloist sings. Spectrograms are given in black and white (left scale) while extracted F0 is given in blue (right scale), total time is given at the bottom. All figures have not the same quality because of the differences in recordings and in background instruments (from none to all).

These research findings demonstrate that vocal effects (or vocalizations) remain similar across generations of singers while the global structure and instrumentarium have been adapted to globalized musical standards. In Gwoka, the singing voice is an instrument used to trace and find one's way. As a result there is a crucial need for the preservation and transmission of this musical culture across generations. Therefore, it makes sense that Gwoka has become a centrepiece of Guadeloupean culture. 


\section{VOICING AND THE PRESERVATION OF GUADELOUPEAN IDENTITY}

It is not a mere coincidence if voicing is a key element in the transmission processes of Gwoka. In oral traditional societies, voice supports words and language but it is also a source of non-verbal creativity through vocal techniques that value sound production over the communication of verbal meaning. The fact that improvisation skills are enhanced in Gwoka through lokans reveals the importance of playing with words and with voice timbre, as for example, in the creaky voice.

\section{Voicing as a means to preserve Guadeloupean creole}

The most important cultural heritage that Gwoka preserves is arguably the fact that it is sung only in Guadeloupean Creole. During slavery, Africans developed a new form of communication by relying on what they heard from their French masters and on their original languages. According to Jerome Camal, a strong linguistic debate still exists on how and when the creolization process occurred (2011), for instance whether there is a continuum between Creole languages from different regions (Alleyne 1971). However as noted by Jean Bernabé, 'Africans and Europeans were forced by History to invent a linguistic tool, which, after the first generation of children born in colonies, has turned into a native language, and became the mother tongue for African communities' (1983). Creole languages from Guadeloupe, Martinique and Réunion, are commonly understood as having a French lexical basis. This means that Creole is a mixture of African words with European expressions and sentence structures.

As in any language, there is an evolution of Creole languages. By proposing the western model as the universal reference, by Christianizing the African or afrodescendant populations, colonization played a major role in the changes that occurred in Creole languages. Moreover, until the 1970s, French was the only spoken and written language taught at school, while Creole was considered as the language of vié nèg, leading to low success rates in the school system (Schnepel 2004). The fact that this territory still belongs to France indicates how strong the weight of colonization has been on Guadeloupean culture. In Jerome Camal's view, the evident lack of interest for written Creole was the result of its "bastardization." During the last decade, the relationship that the Guadeloupean people have with their language has changed significantly. Access to written Guadelouian Creole has greatly increased: since the 1982 Savary law, it has been taught at school in Guadeloupe and also in metropolitan France, while more and more media are broadcast in Creole.

In any transmission processes, there are movements, mutations, and changes. In Gwoka, as in much traditional music, even though people carry a legacy that they try to preserve, this legacy is affected by the construction of a cultural heritage. However, in Gwoka transmission processes, several fundamental aspects are preserved such as the Guadeloupean Creole language, metaphorical capacities, vocal ornamentations, and structural and rhythmic musical cues. It must be noted that the singer's lack of a strong knowledge of the language tends to affect his vocabulary when improvising and consequently negatively affects creative capacity in Gwoka.

During the last decade, there has been a tendency among young generations to 'frenchify' Creole due to the diglossic context. The exposure to western culture and languages via radio and television programmes, social networks and schooling has encouraged young Creole people to learn languages (mainly French, but also American English) that interfere with their own language. Today, under the influence of French language, unconsciously or not, singers also tend to lose their Creole accent and the depth of the language that is vital to the integrity of Gwoka music, which can also be attributed to the broader effects of westernization and globalization on cultural diversity. 


\section{Gwoka singing: Between resistance and 'Guadeloupeanity'}

Gwoka has gradually become a practice of belonging and 'Guadeloupeanity'. While citizenship refers to the French state, Guadeloupeanity refers to being together and living together in order to become or to build a strong Guadeloupean community, to share the same memory and history, to invest in the life of this community. Gwoka is a music that was born from slavery, a tragedy as well as a genocide engraved in the memory of the Guadeloupeans. It is impossible to discuss this music without mentioning its history. One needs to be fully exposed to Guadeloupean culture to understand its spirit. For the Guadeloupeans, singing is an opportunity to remember their past, their history, and it is an occasion to celebrate the rebirth of their culture. People sing in order to assert their identity, their anchorage in Guadeloupean society, precisely because this identity has been suppressed by French colonial power. Because in the context of Gwoka, identity and Guadeloupeanity building is related to colonization, singing is also a form of expression of freedom, a form of liberation from colonial oppression, and consequently a form of resistance to the imposition of French culture, the French language and French national identity.

As mentioned previously, some musicians and activists rejected UNESCO's protection of the Gwoka tradition. According to Lucas Lixinski, UNESCO's obligations 'are to create not a legal system of protection, but rather a system based on listing and policy-oriented protection, including educational programmes and awareness raising generally' (2011). Moreover, 'the Convention is incapable of offering remedies for misappropriation by third parties, particularly when the third party is the state' (Lixinski 2011). In a sense, then, resistance to UNESCO and to the French state, which are associated with colonialism and nationalism in Guadeloupe, is a way of asserting 'Guadeloupeanity'.

Among many others, Gwoka singers Guy Konkèt and Robert Loyson have had a tangible social and political impact on the population through their politically subversive songs. Their lyrics and melodies are a sort of call to awaken people, as reflected by the standard-bearer song 'Gwadloup malad' of the 1967 strikes by Guy Konkèt, which was banned from official radio broadcast:
Wi mé frè la Gwadloup malad oh!
fô nou touvé on rimèd mésié
pou nou sové péyi-la mézanmi oh!
Yes, brothers, Guadeloupe is sick oh! one must find a remedy
to save our beloved country, oh !

as well as 'Kan' a la richesse' by Robert Loyson - about sugar cane workers in plantations - a song with a strong political:

$\begin{array}{ll}\begin{array}{l}\text { Gwadloupéyen pôté on koudèy si la } \\ \text { rékôlt, }\end{array} & \begin{array}{l}\text { Guadeloupeans must keep an eye on their } \\ \text { crops }\end{array} \\ \text { si-w pa pôté on koudèy la } & \text { If you do not watch out } \\ \text { Gwadloup ké anvayi, } & \text { Guadeloupe will be invaded } \\ \text { sa ka gadé pli lwen, } & \text { If you look further } \\ \text { ka tiré pli lwen, } & \text { You can go further } \\ \text { ka vizé pli lwen. } & \text { You can aim further. }\end{array}$

Gwoka transmission processes enact a positive affirmation of a culture that has been rejected by the French colonizers as well as by part of the Guadeloupean population to avoid being considered as outcasts. The rejection of Guadeloupean ancestral culture is the result of an oppressive colonial system. Gwoka is also considered by the singers to be an effective way 
of raising consciousness about citizenship. Indeed, Gwoka music has been used during modern protest movements, including the 2009 general strike. The commitment and work of Lockel demonstrate the extent to which this musical practice represents a civic act and a powerful expression of cultural identity. The mobilization of the people of Guadeloupe following the death in 1985 of Vélo (Marcel Lollia) - the most celebrated tanbouyé - can also be considered as a hommage to Gwoka musicians.

\section{Gwoka singing as a way of unifying the Guadeloupean people}

Today, Gwoka musical practices embody a need to preserve a living popular memory. As in many African diasporic cultures, including West and central African cultures such as Congo and Senegal, to name but a few, music is part of daily life, it is a common expression that helps people to come together and maintain social links. As observed by Emmanuel James Flolu, 'every music is a social fact, a social reality. Individuals or groups of people who live within society make music. It could be said that music making is a lifelong activity of every society' (1996). This is especially true in Africa, where 'music is life; [...] it permeates all daily activities. Music, in Africa, is the soul of whom is ultimately concerned with various customs and religious practices' (Aduonum 1980).

People sing to tell stories; singing is an outlet for the vocalists. For some of them, singing Gwoka is also a way to reconnect with a part of their African ancestral roots or heritage. The Gwoka festival that is held annually in July in Sainte-Anne is an important gathering place for Gwoka musicians. It brings together a very diverse public - different generations, enthusiasts, amateurs and professionals... Musicians who, every Saturday morning, play Gwoka in the pedestrian area of Pointe-à-Pitre demonstrate their belonging to the Guadeloupean community. By doing so in an area that has become a place of worship for Gwoka and its invisible ancestors, they have a huge input in the transmission processes of the music of their island and they add a spiritual dimension to Gwoka.

As can be observed in Gwoka music today, there is a pressing need for bringing people together in order to preserve a common memory that has been fragmented throughout the history of Guadeloupe. Taking part in the léwòz, kout'tanbou, véyé, etc., represents opportunities for the population to gather, share and honour their culture through singing. On those occasions, different generations come together to sing, dance, and play. These events give practitioners an opportunity to transmit a legacy. By observing these moments of impregnation, one sees how committed these people are to Gwoka music. During the léwòz, the audience forms a circle, people clap and respond as a choir. No formal training is required, but one has to be familiar with the conventions pertaining to this traditional musical practice. The newcomers in the audience learn by observing, as well as by making mistakes. Transmission also occurs by imitating the singers as there is no school for teaching vocal techniques.

Gwoka musicians have managed to preserve the essence of their music in the globalized world while integrating musical elements from outside influences (Sitchet 2016). Gwoka barely has a presence in the music industry even though much has been done thanks to the Rèpriz centre which attempts to connect bands with trade fairs such as Womex and Midem. According to Chotard, most of Gwoka musical productions are self-produced, therefore the notion of profitability is not financial, but can be measured in terms of a public gratitude towards the artist (2009). The most well-known Gwoka band is Kan'nida which has garnered international attention. Specializing in wake songs and bouladjèl, this group, led by René and Francky Geoffroy and inclusive of other family members, has been active for more than three decades. Moreover, some Guadeloupean musicians, like Christian Laviso, Jacques SchwarzBart or Franck Nicolas, to name but a few, use $k a$ in their music, which helps to give Gwoka 
music some exposure. The emergence of Jazz Ka has also resulted in Gwoka music being broadcasted all over the world (Camal 2011).

\section{CONCLUSION}

In addition to conveying expressions of sovereignty and self-determination, Gwoka musical practices are perhaps now on the verge of becoming part of the globalized cultural industry. However, musicians tend to experience frustration and concerns even as they work to gain more exposure on the world market. These feelings may be linked to the transmission processes of Gwoka vocal practices, whose goals are to preserve a culture and pass on a legacy to the next generations. Keeping collective memory alive enables the culture of Guadeloupe to survive through song and music by making the people feel grounded in their own lives. A strong identity marker for Guadeloupeans, Gwoka is the most celebrated music on the island. It reflects the soul of the Guadeloupean community and, according to musicians, it represents the soul of Guadeloupe. René Geoffroy, who is Kan'nida's co-leader, plays jazz as a saxophonist and he is still taking sax and harmony lessons. When asked how he sustains the integrity of his santiman when he sings Gwoka, he answers: 'I do not think about anything else when I sing Gwoka'. His point is especially relevant since it reflects his awareness of being situated in-between two musical worlds and his struggle not to 'lose' his culture.

In Guadeloupe, Gwoka is therefore considered to be much more than a music style. Gwoka musicians take clear positions about social issues, they wish to engage the community through their lyrics, in which they assert their Guadeloupean cultural identity as distinct from French national identity. Transmitting Gwoka music involves the transmission of a collective history, the Creole language with its codes and metaphors, as well as the uniqueness of Guadeloupean culture. In a way, singers are chroniclers of their time, they are memory smugglers who educate their audience by evoking shared values through their lyrics. 


\section{REFERENCES}

Aduonum, A. (1980), 'A compilation, analysis and adaptation of selected Ghanaian folk tale songs for use in the elementary general class', Ph.D. thesis, Ann Arbor: University of Michigan.

Alleyne, M. (1971), 'Acculturation and the cultural matrix of creolization', in D. Hymes (ed.), Pidginization and Creolization of Languages, Cambridge, UK: Cambridge University Press, pp. 169-86.

Ambrazeviccius, R. and Leskauskaite, A. (2007), 'Effect of spoken dialect on singing technique in Lithuanian traditional music', Conference on Interdisciplinary Musicology, Tallinn, 15-19 August.

Barras, C., Geoffrois, E., Wu, Z. and Liberman, M. (2000), 'Transcriber: Development and use of a tool assisting speech corpora production', Speech Communication, 33:1, pp. 5-22.

Bensignor, F. (2014), 'Le Gwoka, Patrimoine Culturel Immatériel' ('Gwoka intangible cultural heritage'), Hommes et Migrations, 1308:2014, pp. 184-89.

Bernabé, J. (1983), Fondal-Natal, Grammaire Basilectale Approchée des Créoles Guadeloupéen et Martiniquais, Paris: L'Harmattan.

Boersma, P. and Kovaccic, G. (2006), 'Spectral characteristics of three styles of Croatian folk singing', Journal of Acoustic Society of America, 119:3, pp. 1805-16.

Delumeau, F. (2006), 'Une Description Linguistique du Créole Guadeloupéen dans la Perspective de Génération Automatique d'Énoncés' ('A linguistic description of Guadeloupean Creole in an automatic text generation perspective'), Ph.D. thesis, Paris, University of Nanterre-Paris 10.

Camal, J. (2011), 'From Gwoka Modènn to Jazz Ka: Music, nationalism, and creolization in Guadeloupe', Ph.D. thesis, Washington, University of St. Louis.

(2013), 'Gwoka et Atonalité, une Question de Contexte' ('Gwoka and aonality, a matter of context'), https://tanbouolwen.com/2013/06/19/gwoka-et-atonalite-unequestion-de-contexte/. Accessed 7 February 2017.

Chotard, O. (2008), 'Les Sillons du Gwoka' ('Gwoka's grooves'), MA thesis, Tours: Université François Rabelais.

Emoff, R. (2009), Music and the Performance of Identity on Marie-Galante, French Antilles, Surrey: Ashgate.

Eriksen, T. H. (2001), 'Between universalism and relativism: A critique of the UNESCO concepts of culture', in J. Cowan, M.-B. Dembour and R. Wilson (eds), Culture and Rights: Anthropological Perspectives, Cambridge: Cambridge University Press, pp. $127-48$.

Flolu, E. J. (1996), 'Music in traditional Africa cultures: Beneath and beyond the utilitarian factor', The African Music Educator, 8, pp. 8-13.

Fox, A. (2004), Real Country: Music and Language in Working-Class Culture, Durham, NC: Duke University Press.

Frith, S. (1996), 'Music and identity', in S. Hall and P. du Gay (eds), Questions of Cultural Identity, London: Sage, pp. 108-27.

Gama, R. and Sainton, J.-P. (1985), Mé 67: Mémoire d'un Événement (May 67: In Memory of an Event), Port-Louis: Lespwisavann. 
Kerlin, J. (2008), The Transmission of Song Among the New York Irish: Teaching, Learning, and Irish Sensibility, Saarbrücken: VDM Verlag.

Labarthe, G. (1998), 'Un Film sur le Gwoka Guadeloupéen' ('A film on Guadeloupean Gwoka'), Cahiers d'Ethnomusicologie, 11:1998, pp. 311-15.

Lafontaine, M. C. (1983), 'Le Carnaval de l'Autre: à Propos d'Authenticité en Matière de Musique Guadeloupéenne' ('The other's carnival: About authenticity regarding Guadeloupean music'), Les Temps Modernes: Special Issue on the French Caribbean, 39:441\&442, pp. 2126-73.

Lameca (La Médiathèque Caraïbe) (2015), 'Les Rythmes', http://www.lameca.org/dossiers/gwoka/sommair.html. Accessed 17 May 2017.

Laumuno, M. H. (2011), Gwoka et Politique en Guadeloupe: 1960-2003, 40 Ans de Construction du Pays (Gwoka and Politics in Guadeloupe: 1960-2003: 40 Years of Local Establishment), Paris: L'Harmattan. (2012), Et le Gwoka s'est Enraciné en Guadeloupe: Chronologie d'un Patrimoine Immatériel Sensible (And Gwoka Put down Roots in Guadeloupe: Chronology of a Sensitive Intangible Heritage), Paris: Gourbeyre.

(2013), Une Histoire du Gwoka en Guadeloupe au XXe siècle (A Gwoka History in Guadeloupe in the 20th Century), Guadeloup: Jasor.

Ligue des droits de l'homme (2013), 'Guadeloupe, Mai 1967, un Drame Français' (Guadeloupe, May 1967, a French tragedy'), http://www.ldh-france.org/GuadeloupeMai-1967-un-drame/. Accessed 7 February 2017.

Lindestad, P. A., Södersten, M., Merker, B. and Granqvist, S. (2001), 'Voice source characteristics in Mongolian "throat singing" studied with high-speed imaging technique, acoustic spectra, and inverse filtering', Journal of Voice, 15:1, pp. 78-85.

Livingstone, S. R., Peck, K. and Russo, F. A. (2013), 'Acoustic differences in the speaking and singing voice', Proceedings of Meeting Acoustics, 19:1, pp. 1-5.

Lixinski, L. (2011), 'Selecting heritage: The interplay of art, politics and identity', European Journal of International Law, 22:1, pp. 81-100.

Lockel, G. (1981), Traité de Gro Ka Modên: Initiation à la Musique Guadeloupéenne (Gro Ka Modên Treaty: Initiation to Guadeloupean Music), N.p., Baie Mahault.

Mendes, A. P., Rodrigues, A. F. and Guerreiro, D. M. (2012), 'Acoustic and phonatory characterization of the Fado voice', Journal of Voice, 27:5, pp. 655.e9-e15.

Patrimoine Culturel Immatériel (2012), 'Le Bouladjèl', www.culturecommunication.gouv.fr/content/download/83526/629999/version/1/file/ gwoka.pdf. Accessed 17 May 2017.

Rosemain, J. (1988), 'L'Influence de l'Eglise sur les Danses des Esclaves à la Martinique et à la Guadeloupe XVIIe, XVIIIe, XIXe Siècles' ('Church influence on slaves' dances in Martinique and Guadeloupe, 17th, 18th, 19th Centuries'), in Les Musiques Guadeloupéennes, Paris: Édition Caribéennes, pp. 55-60.

Sainton, J. (2006), 'Les Langues Créoles à Base Lexicale Française de la Caraïbe: Phonétique, Phonologie et Variation' ('Caribbean Creole languages with a French lexical basis: Phonetics, phonology and variation'), Ph.D. thesis, Paris: Ecole Pratique des Hautes Etudes.

Schnepel, E. M. (2004), In Search of a National Identity: Creole and Politics in Guadeloupe, Hamburg: H. Buske. 
Sitchet, P.-E. (alias Sitson Gino) (2016), 'Le Gwoka: De l'Unesco aux Nouvelles Perspectives' ('Gwoka: From Unesco to new perspectives'), Africultures, http://www.africultures.com/php/?nav $=$ article\&no=13466. Accessed 7 February 2017.

Sitchet, P.-E. and Tahon, M. (2016), 'Le Voisement dans le Gwoka: entre le Parlé et le Chantè' ('Voicing in Gwoka: Between speaking and singing'), Association Française d'Informatique Musicale, Journées d'Informatique Musicale, Albi, France, pp. 15359.

Tahon, M. and Sitchet, P.-E. (2015), 'Interest of a mixed approach combining paradigmatic method and signal processing. Case study: Analysis of two musical pieces of Gwoka from Guadeloupe', International Colloquium: Innovant Tools and Methods for Music and Signal Processing Teaching, St. Etienne.

(2016), 'La Nasalité dans le Répertoire Gwoka de la Guadeloupe' ('Nasality in Gwoka repertoire from Guadeloupe'), Congrès Français d'Acoustique, Le Mans.

UNESCO (2014), 'Dossier de Candidature $n^{\circ} 00991$ pour l'Inscription sur la Liste Représentative du Patrimoine Culturel Immatériel de l'Humanité en 2014', www.unesco.org/culture/ich/doc/download.php?versionID=30360. Accessed 7 February 2017.

\section{APPENDIX}

\section{Glossaire}

Boulà: big drum with a lower pitch, is the one that keeps the rhythm continuously

Bouladjèl: vocal transposition belonging to Gwoka rhythms and polyrhythms, this set is accompanied by the public hand raps.

Chantè: singer

$K a$ : drum. The word comes from the French 'Gros Quart' that described one of the huge barrels of salt meat or wine in used during the colonial era.

Kout' tanbou: it is an informal demonstration of gwoka that takes the form of a friendly visit. This is a marked moment of conviviality.

Makè: small drum and sharp in tone, which is used for improvisation and solos. Phrases are a musical translation of the dancer's steps

Mizik a vié nèg: vagrants music, savages music

Léwòz: social evening, the léwoz is a night of popular communion around the drum. This is the most traditional form of gwoka.

Répondè: choir/chorus

Tanbouyé: drummer

Rèpriz Center: Center for traditional and popular music and danses

Véyé: wake

\section{SUGGESTED CITATION}

Tahon, M. and Sitchet, P.-E. (2017), 'The transmission of voicing in traditional Gwoka: Between identity and memory', Journal of Interdisciplinary Voice Studies, 2:2, pp. 157-75, doi: 10.1386/jivs.2.2.157_1 


\section{CONTRIBUTOR DETAILS}

Marie Tahon is currently with the IRISA in the team Expression on a post-doctoral position. She received her Ph.D. degree in informatics and signal processing from the University of Paris-Sud (Orsay, France) in 2012. She has been with the LIMSI-CNRS in the team Affective and Social dimensions of Spoken Interactions. She has been a teaching and research assistant in acoustics with the Conservatoire National des Arts et Métiers (CNAM, Paris, France). She also received her Diploma of Music Studies in clarinet in 2011. Her research interests concern acoustic analysis of sound signals, musical acoustics, musical and expressive speech modelling (timbre, rhythm, articulation and intonation).

Contact: IRISA, 6 rue de Kérampont, 22300 Lannion, France.

E-mail: marietahon@noath.net

Pierre-Eugène Sitchet (artist name Gino Sitson) is a New York-based, French-American originally from Cameroon vocalist, composer. He holds a Ph.D. in musicology from ParisSorbonne University under the supervision of Professor Jean-Marc Chouvel. He also earned a MS degree in education sciences. His work focuses on music cognition, expressive properties of the voice and the process of transmitting music from the 'black' diaspora. Among them, he is particularly interested in Gwoka music from Guadeloupe. Under his stage name, he has already released seven albums. He appeared in the 2009 PBS documentary film 'the music instinct: science and song', featuring Bobby McFerrin, Daniel Levitin, Olivier Sacks, Daniel Barenboim and Yo-Yo Ma. He is a UNICEF CAMEROON Goodwill Ambassador.

Contact: Institut de recherche en Musicologie (IReMus), 2 rue de Louvois, 75002 Paris, France.

E-mail: pesitchet@gmail.com

Marie Tahon and Pierre-Eugène Sitchet have asserted their right under the Copyright, Designs and Patents Act, 1988, to be identified as the authors of this work in the format that was submitted to Intellect Ltd. 
